\title{
BIBLIOCRIME: BENTUK DAN PENANGGULANGAN PADA KOLEKSI BUKU DI DINAS PERPUSTAKAAN DAN KEARSIPAN KOTA LUBUKLINGGAU
}

\author{
Lilis Yuliana ${ }^{1}$ \\ Universitas Bengkulu \\ lilisyuliana3796@gmail.com¹, \\ Purwaka $^{2}$ \\ Universitas Bengkulu \\ Lailatus Sa'diyah ${ }^{3}$ \\ Universitas Bengkulu \\ lailasadiah@unib.ac.id ${ }^{3}$
}

\begin{abstract}
ABSTRAK
Tujuan dari penelitian ini adalah mengetahui bentuk dan penanggulangan bibliocirme di Dinas Perpustakaan dan Kearsipan Kota Lubuklinggau. Metode yang di gunakan adalah metode kualitatif dengan jenis penelitian kualitatif deskriptif, pelaksanaan wawancara pada objek penelitian sebanyak 4 orang yang merupakan tenaga pustakawan Teknik penentuan informan yang digunakan adalah teknik purposive sampling. Hasil penelitian menunjukkan bahwa bentuk bibliocrime yang terjadi adalah: 1) Vandalisme, mencoret buku, menggarisbawahi, menstabilo dan men tipe-x. 2) Mutilasi, merobek sampul ataupun lembaran buku. 3) Pencurian, terindikasi namun tanpa data. 4) Peminjaman tidak sah, meminjam kartu orang lain dan surat jaminan. Penanggulangan yang di lakukan adalah 1) Pemasangan sistem keamanan berupa cctv 2) Penyediaan loker 3) Pengawasan yang dilakukan oleh pustakawan yang menjaga ruang koleksi 4) Kartu anggota perpustakaan 5) Penyediaan kartu khusus untuk anak-anak.
\end{abstract}

Kata Kunci: Bibliocrime, Penanggulangan bibliocrime, koleksi buku

\section{PENDAHULUAN}

Perpustakaan sebagai tempat pencarian informasi yang dibutuhkan oleh para pengguna melalui buku-buku yang dimiliki. Perpustakaan menjadi tempat berkumpulnya buku-buku yang memiliki ragam jenis sasaran juga gagasan dengan tujuan penyajian yang berbeda-beda, tidak hanya pelajar namun mahasiswa dan masyarakat umum menjadi sasaran dibangunnya sebuah perpustakaan, dengan tujuan sebagai bagian dari cara untuk mencerdaskan kehidupan bangsa. Perpustakaan menjadi salah satu tempat favorit bagi para penikmat buku, tidak hanya itu sebuah perpustakaan yang dibangun dengan konsep memanjakan pengguna atau pemustaka maka daya tarik yang diberikan akan lebih tinggi lagi, khususnya untuk para pecinta buku dengan fasilitas yang nyaman. Masyarakat harus 
menyadari bahwa pemustaka merupakan masyarakat umum atau tidak menjurus pada satu atau dua kalangan saja, namun bersifat menyeluruh dan tidak jarang pengunjung perpustakaan merupakan kalangan pendidikan, sementara masyarakat lainnya berada disektor lain.

Salah satu faktor dari kerusakan koleksi buku disebabkan oleh penyalahgunaan koleksi atau bibliocrime yang dilakukan oleh manusia itu sendiri. Kejahatan terhadap buku atau disebut bibliocrime dapat menjadi titik awal yang mengancam keberadaan buku. Bibliocrime muncul dapat didasari atas kesengajaan atau ketidaksengajaan. Bibliocrime yang didasari atas kesengajaan terjadi dan telah direncanakan sebelum masuk kedalam perpustakaan, dan ketidak sengajaan terjadi tanpa adanya niat awal sebelum masuk ke perpustakaan. Ada sebab-sebab tertentu yang mengakibatkan kedua faktor tersebut dapat terjadi. Adanya bibliocrime membuat resah bagi perpustakaan karena merasa dirugikan secara ilmu juga secara materi. Bentuk kerugian lain yang disebabkan oleh bibliocrime adalah bahan pustaka akan cepat rusak jika terus menerus terjadi bibliocrime, koleksi bahan pustaka dalam perpustakaan akan cepat habis atau hilang karena ada pencurian terhadap buku.

Sebagai perpustakaan yang berdiri megah ditengah-tengah masyarakat menjadikan Dinas Perpustakaan dan Kearsipan Kota Lubuklinggau pusat pencarian koleksi bahan pustaka untuk kebutuhan informasi pemustaka. Pengunjung yang berdatangan tidak hanya pelajar namun juga masyarakat umum. Hal ini menjadikan banyak sifat dan sikap pemustaka terhadap buku. Bagi pemustaka yang telah faham bagaimana seharusnya menjaga buku, mungkin akan menjadi teman yang baik untuk buku, namun bagi pemustaka yang belum faham justru akan menjadi musuh bagi buku.

Berdasarkan Laporan Dinas Perpustakaan dan Kearsipan Kota Lubuklinggau pada tahun 2019 koleksi buku yang dimiliki adalah 29,714 judul dan 86,360 eksemplar dan juga masih terdapat koleksi lainnya. Jumlah tenaga kerja yang ada di perpustakaan adalah 51 orang tenaga kerja dengan 4 orang pustakawan atau berlatarbelakang pendidikan khusus perpustakaan. Selain sebagai tempat rujukan bagi para pelajar, pemustaka yang datang juga berasal dari masyarakat umum sehingga potensi adanya bibliocrime pasti terjadi.

Sebagai penunjang penelitian dibutuhkan adanya penelitian-penelitian terdahulu untuk memberikan referensi sumber rujukan dan hasil penelitian. Penelitian terdahulu yang mendukung dengan judul penelitian diambil dari 4 penelitian terdahulu, yaitu:

1. Penelitian pertama berjudul "Tindakan Penyalahgunaan Koleksi: Studi Kasus di Perpustakaan Universitas Sumatera Utara" oleh Yousi Anggi Saragih, Universitas Sumatera Utara tahun 2017. Penelitian ini bertujuan untuk mengetahui jenis tindakan penyalahgunaan koleksi, pelaku penyalahgunaan koleksi, mengetahui dampak kerugian yang dialami Perpustakaan Universitas Sumatera Utara, faktor-faktor yang mendorong seseorang melakukan penyalahgunaan koleksi, dan cara yang digunakan untuk pencegahan dari tindakan penyalahgunaan koleksi. Metode yang digunakan metode kualitatif. Hasil: pelaku dari tindakan penyalahgunaan koleksi adalah mahasiswa, dosen, dan pegawai Perpustakaan, jenis penyalahgunaan: melepas pita magnet, melemparkan buku melalui jendela perpustakaan, keluar melalui pintu khusus, meminjam slip dan KTM mahasiswa lain, merobek buku, dan menandai kalimat dengan stabilo atau pulpen. 
2. Penelitian kedua berjudul "Penyalahgunaan Koleksi di Perpustakaan Nasional Republik Indonesia” oleh Kevin Berlianto Imaman, Perpustakaan Nasional Republik Indonesia tahun 2018, penelitian ini membahas mengenai berbagai macam bentuk penyalahgunaan koleksi yang terjadi di Perpustakaan Nasional Republik Indonesia dan upaya yang telah dilakukan oleh Perpustakaan Nasional Republik Indonesia dalam menanggulanginya. Hasil: bentuk penyalahgunaan koleksi meliputi pencurian koleksi, perobekan koleksi, vandalisme koleksi, dan peminjaman tidak sah. Upaya yang telah dilakukan adalah menggunakan perangkat teknologi berupa CCTV dan memasukan pelaku penyalahgunaan koleksi pada daftar hitam.

3. Penelitian ketiga berjudul "Kebijakan Tindakan Bibliocrime di UPT Perpustakaan Institut Teknologi Bandung, oleh Maria Rosamistika Lalu, Richard Togaranta Ginting dan I Putu Suhartika, Institut Teknologi Bandung tahun 2019. Penelitian ini bertujuan untuk mengetahui bagaimana kebijakan tindakan bibliocrime di UPT Perpustakaan Institut Teknologi Bandung. Penelitian ini merupakan penelitian deskriptif dengan pendekatan kualitatif. Hasil: adalah tindakan pencurian (berupa koleksi buku), perobekan (koleksi yang diminati), peminjaman tidak sah (berupa terlambat mengembalikan) dan vandalisme (berupa mencoret buku menggunakan stabilo, pensil, pulpen serta memberikan tipe $\mathrm{x}$ ).

4. Penelitian keempat berjudul "Motif Perilaku Bibliocrime di UPT Perpustakaan UIN Raden Fatah Palembang" oleh Linda Maryani dan Herlina, UIN Raden Fatah Palembangtahun 2019. Tujuan dari penelitian ini adalah untuk mengetahui perilaku, motif, dampak, dan upaya pencegahan terjadinya bibliocrime. Hasil: perilau bibliocrime yang pernah terjadi adalah perobekan dan vandalisme. Sedangkan jenis yang terjadi adalah peminjaman tidak sah dan perobekan.. Motifnya yaitu terjadi karena pemustaka dan pustakawan itu sendiri. Dampak kerugian berupa finansial dan sosial. Upaya pencegahannya yaitu pemberian cctv dan security gate, melakukan pendidikan pemakai dan keamanan fisik.

Berdasarkan dari keempat perbandingan penelitian diatas dan latar belakang masalah yang terjadi, peneliti memiliki kesamaan dengan penelitian sebelumya yaitu sama-sama membahas mengenai bibliocrime di masing-masing perpustakaan sebagai tempat penelitian. Keempat penelitian di atas meneliti mengenai tindakan bibliocrime, pengaruh bibliocrime, sedangkan peneliti sendiri ingin mengetahui bentuk penanggulangan bibliocrime di Dinas Perpustakaan dan Kearsipan Kota Lubuklinggau. Perbedaan penelitian terdahulu dengan penelitian yang akan peneliti lakukan adalah penelitian ini lebih menekankan pada bentuk dan penanggulangannya terhadap koleksi buku di Dinas Perpustakaan dan Kearsipan Kota Lubuklinggau.

Adapun fokus masalah dalam penelitian ini adalah apa saja bentuk bibliocrime yang terjadi di Dinas Perpustakaan dan Kearsipan Kota Lubuklinggau dan bagaimana bentuk penanggulangan bibliocrime di Dinas Perpustakaan dan Kearsipan Kota Lubuklinggau. Tujuan dari penelitian adalah untuk mengetahui bentuk-bentuk bibliocrime yang terjadi di Dinas Perpustakaan dan Kearsipan Kota Lubuklinggau dan mengetahui upaya penanggulangan bibliocrime di Dinas Perpustakaan dan Kearsipan Kota Lubuklinggau. Hasil 
penelitian ini bisa menjadi sumber informasi baru bagi institusi Dinas Perpustakaan dan Kearsipan Kota Lubuklinggau dalam penanganan bibliocrime serta menjadi sumber informasi baru bagi Dinas Perpustakaan dan Kearsipan Kota Lubuklinggau mengenai bentuk penanggulangan bibliocrime.

\section{TINJAUAN PUSTAKA}

\section{Bibliocrime}

Secara harafiah istilah bibliocrime terdiri atas kata biblio dan crime, istilah kata biblio bukan hanya istilah yang digunakan untuk buku saja, melainkan merujuk pada hal-hal yang berkaian dengan pustaka. Istilah pustaka juga sering disebut sebagai koleksi perpustakaan. Koleksi di sini tidak hanya koleksi berupa buku, melainkan seluruh koleksi yang ada pada perpustakaan. Sedangkan crime berarti kriminal atau kejahatan.

Menurut Maryani dan Herlina (2019:113) bibliocrime adalah suatu bentuk tindakan kejahatan terhadap koleksi, sedangkan menurut Lalu (2019) bibliocrime atau tindakaan penyalahgunaan merupakan tindakan kejahatan yang dilakukan oleh pemustaka terhadap koleksi perpustakaan. Dapat disimpulkan bahwa bibliocrime merupakan tindakan penyalahgunaan koleksi yang ada di perpustakaan berupa kejahatan-kejahatan terhadap koleksi berupa vandalisme, mutilasi, peminjaman tidak sah dan bentuk kejahatan yang lainnya yang dapat merugikan perpustakaan baik secara finansial ataupun sosial.

\section{Bentuk Bibliocrime}

Bentuk bibliocrime merupakan wujud secara nyata terjadinya kejahatan terhadap buku yang dapat dilihat serta dapat dirasakan dampaknya. Menurut Obiagwu dalam Lalu dkk (2019:2) tindakan penyalahgunaan koleksi atau bibliocrime dapat digolongkan menjadi empat macam yaitu :

1. Vandalisme (vandalism) adalah tindakan perusakan bahan pustaka dengan menulisi, mencorat-coret, memberi tanda khusus, membasahi, membakar dan lain-lain.

2. Pencurian (thef) adalah tindakan mengambil bahan pustaka tanpa melalui prosedur yang berlaku di perpustakaan dengan atau tanpa bantuan orang lain.

3. Mutilasi (mutilation) adalah tindakan perobekan, pemotongan, penghilangan dari artikel, ilustrasi dari jurnal, majalah, buku, ensiklopedia dan lain-lain tanpa atau dengan menggunakan alat.

4. Peminjaman tidak sah (unautorized borrowing) adalah kegiatan pengguna yang melanggar ketentuan peminjaman.

\section{Penanggulangan Bibliocrime}

Penanggulangan bibliocrime merupakan suatu bentuk pencegahan maupun meminimalisir adanya bibliocrime baik oleh pustakawan, tenaga ahli yang dilakukan oleh manusia maupun dengan bantuan teknologi ataupun perangkat yang kemudian di bagikan kepada pengguna perpustakaan juga pustakawan baik melalui pendidikan pustaka atupun dalam bentuk lainnya yang bertujuan agar pengguna dan pustakawan melek akan dampak adanya bibliocrime. Menurut Syaikhu dalam Nuansa dan Yuli (2017) untuk menjaga dan melindungi keutuhan koleksi perpustakaan, perlu diperhatikan tiga aspek, yaitu: 
1. Keamanan fisik (physical security) perpustakaan, yang mencakup arsitektur, staff keamanan, dan perangkat keras, seperti perlindungan pada pintu dan jendela. Penanggulangan ini dapat di lakukan untuk mencegah adanya vandalisme, mutilasi juga dapat untuk mencegah terjadinya pencurian.

2. Penggunaan teknologi keamanan seperti barcode, radio frequency identification (RFID), dan closed circuit television (CCTV). Penanggulanagn ini dapat dilakukan untuk mencegah terjadinya pencurian dan peminjaman tidak sah.

3. Kebijakan keamanan, prosedur, dan rencana.

Menurut Imaman (2018) dalam jurnal penelitiannya menyebutkan bahwa upaya penanggulangan penyalahgunaan koleksi yaitu:

1. Keamanan Fisik ( layout )

Keamanan fisik perpustakaan dalam hal ini adalah segala sesuatu yang mencakup keamanan lingkungan fisik perpustakaan.

2. Kebijakan dan prosedur keamanan

Upaya pencegahan penyalahgunaan koleksi yang kedua adalah mengadakan program bimbingan pemustaka. Selanjutnya kebijakan dan prosedur keamanan kedua adalah dengan memberlakukan sanksi yang tegas bagi pelaku penyalahgunaan koleksi.

3. Penggunaan teknologi keamanan

Yaitu RFID (Radio Frequency Identification) dan kamera pengawas CCTV (Closed Circuit Television).

\section{METODE PENELITIAN}

Penelitian ini menggunakan jenis penelitian kualitatif deskriptif. Pendekatan kualitatif adalah sebagai prosedur penelitian yang menghasilkan data deskriptif berupa kata-kata. Metode penelitian kualitatif adalah metode penelitian yang berlandaskan pada filsafat positifisme digunakan untuk meneliti pada kondisi objek alamiah dimana peneliti adalah sebagai instrumen kunci (Sugiyono, 2014:9). Penelitian kualitatif bertujuan untuk mendapatkan pemahaman yang sifatnya umum terhadap kenyataan sosial dari segi prespektif. Penelitian ini menggunakan teknik purposive sampling. Sampel penelitian anatara lain pustakawan pelestarian bahan pustaka, pustakawan pelaksana, staf sirkulasi bagian pengembalian dan staf sirkulasi bagian peminjaman. Penelitian ini menggunakan teknik observasi, wawancara dan dokumentasi.

\section{HASIL DAN PEMBAHASAN}

Peneliti menguraikan hasil sesuai dengan data yang diperoleh peneliti melalui wawancara, observasi dan dokumentasi terhadap informan penelitian yang telah ditentukan.

\section{Bentuk Bibliocrime di Dinas Perpustakaan dan Kearsipan Kota Lubuklinggau}

Bibliocrime merupakan kejahatan terhadap koleksi bahan pustaka yang terjadi di perpustakaan, salah satu objek kejahatan yang dilakukan yaitu terhadap koleksi buku. Bukubuku yang terdampak bibliocrime juga memiliki empat bentuk kejahatan yang sering menjadi pembahasan. Pernyataan oleh Obiagwu yang dikutip dalam Lalu Maria Rosamistika dkk (2019), bentuk bibliocrime yaitu pencurian, vandalisme, peminjaman tidak sah dan mutilasi, 
hal ini sejalan dengan bentuk kejahatan yang terjadi di perpustakaan. Pada beberapa perpustakaan bentuk bibliocrime dapat berbeda-beda sesuai dengan kejahatan yang dilakukan. Berikut ini merupakan pembahasan dari masing-masing bentuk bibliocrime.

\section{Pencurian (thef)}

Tindak penyalahgunaan koleksi berupa pencurian koleksi bahan pustaka merupakan sebuah kejahatan yang dilakukan baik oleh pemustaka juga pelaku kejahatan lain baik yang telah terencana atau tidak terencana. Berdasarkan penelitian yang telah dilakukan di Dinas Perpustakan dan Kerasipan Kota Lubuklinggau terindikasi adanya pencurian koleksi buku, kasus yang pernah terjadi yaitu menghilangkan koleksi buku yang dipinjam, respon dari pemustaka yang menghilangkan pun berbeda ada yang langsung mengakui kepada pustakawan bahwa buku yang dipinjam telah hilang dan ada juga yang tidak melaporkannya. Untuk tindakan selanjutnya bagi para pemustaka yang menghilangkan koleksi buku yang telah dipinjam adalah dengan mengganti buku yang hilang dengan buku baru dengan judul yang sama, perustakaan tidak menerima penggantian buku dalam bentuk uang. Hal yang menjadi kekurangan peneliti dalam hal ini adalah tidak adanya data riil yang didapatkan, sebab berdasarkan wawancara yang dilakukan tidak ada data yang dapat di berikan atau di tunjukan baik pelaku ataupun jumlah kasus pencurian koleksi buku yang pernah terjadi..

Sistem keamanan yang dimiliki Dinas Perpustakaan dan Kearsipan Kota Lubuklinggau terbilang cukup memadai dengan adanya cctv juga tenaga pustakawan yang menjadi pemantau para pemustaka serta desain ruangan yang mendukung adanya pengawasan bagi para pemustaka.

\section{Vandalisme (vandalism)}

Vandalisme merupakan kejahatan terhadap buku berupa mencoret, menstabilo, tipe-x dan lain sejenisnya. Berikut merupakan tabel hasil pengecekan buku terdampak vandalisme.

Tabel 1 Hasil Pengecekan Buku Terdampak Vandalisme oleh Peneliti

\begin{tabular}{|c|l|c|c|c|}
\hline No. & \multicolumn{1}{|c|}{ Rak buku } & Coret & Stabilo & Tipe x \\
\hline 1. & Agama & 16 & 1 & \\
\hline 2. & Masalah dan Jasa Sosial & 11 & 1 & 1 \\
\hline 3. & Pendidikan & 17 & & \\
\hline 4. & Ilmu-Ilmu Murni & 15 & & \\
\hline 5. & Fiksi Indonesia & 13 & 1 & \\
\hline 6. & Manajemen Rumah Tangga dan Keluarga & 4 & & \\
\hline 7. & Ilmu Hayati & 7 & & \\
\hline 8. & Manajemen dan Jasa Pendukung & 22 & & \\
\hline 9. & Ilmu Pertanian dan Teknologi & 3 & & \\
\hline 10. & Teknologi & & & \\
\hline 11. & Teknik dan Kegiatan Berkaitan & 2 & & \\
\hline 12. & Kedokteran dan Kesehatan & 5 & & \\
\hline 13. & Kesenian, Hiburan dan Olahraga & & & \\
\hline 14. & Perikanan & & & \\
\hline 15. & Teknik Kimia dan Teknologi & 2 & & \\
\hline
\end{tabular}




\begin{tabular}{|c|l|c|c|c|}
\hline 16. & Manufaktur Produk untuk Keperluan Khusus & 1 & & \\
\hline 17. & Bangunan & 2 & & \\
\hline 18. & Geografi dan Sejarah Umum & & & \\
\hline 19. & Perkebunan & 3 & & \\
\hline 20. & Ilmu Ekonomi & 1 & & \\
\hline 21. & Filsafat & 4 & & \\
\hline
\end{tabular}

(Sumber: Data olahan peneliti, 2020)

Berdasarkan penelitian yang telah dilakukan kasus penyalahgunaan koleksi berupa vandalisme terdapat 135 buku yang terdampak vandalisme dengan rincian yaitu 128 buku tercoret, 3 buku di stabilo dan 2 buku di tipe-x. Berdasarkan hasil tersebut dapat dilihat bahwa tingkat vandalisme yang terjadi di Dinas Perpustakaan dan Kearsipan Kota Lubuklinggau tidak terlalu tinggi jika dilihat dari jumlah koleksi buku yang dimiliki oleh perustakaan, namun merupakan bentuk kejahatan tehadap koleksi buku yang paling tinggi dibanding dengan ketiga kejahatan koleksi buku yang lain yang ada di Dinas Perpustakaan dan Kerasipan Kota Lubuklinggau.

Berdasarkan hasil penelitian yang telah peneliti laksanakan terdapat tiga judul buku yang paling tinggi tingkat vandalismenya yaitu buku pada rak manajemen jasa pendukung dengan 22 kasus, pendidikan dengan 17 kasus, dan agama dengan 16 kasus. Dapat dikatakan bahwa hasil wawancara dengan hasil penelitian yang telah dilakukan oleh peneliti memiliki hasil yang berbeda mengenai jenis buku yang paling banyak terdampak vandalisme, dan menjadi sebuah catatan tersendiri bagi pihak perpustakaan untuk lebih meningkatkan keamanan terhadap kejahatan berupa vandalisme sebab tidak dapat dipungkiri bahwa bukubuku yang terlihat rapi di rak dan dalam keadaan baik-baik saja telah terbebas dari vandalisme, untuk itu pustakawan diharapkan dapat lebih meminimalisir hal tersebut.

\section{Mutilasi (mutilation)}

Mutilasi merupakan kejahatan terhadap bahan pustaka dengan merobek dan sejenisnya bahan pustaka berupa buku serta bahan pustaka lain dalam sebuah perpustakaan dengan tidak bertanggungjawab. Berikut merupakan tabel hasil pengecekan buku terdampak mutilasi.

Tabel 2 Hasil Pengecekan Buku Terdampak Mutilasi oleh Peneliti

\begin{tabular}{|l|l|c|c|}
\hline No. & \multicolumn{1}{|c|}{ Rak buku } & Sobek & Lepas \\
\hline 1. & Agama & 7 & 1 \\
\hline 2. & Masalah dan Jasa Sosial & 2 & - \\
\hline 3. & Pendidikan & 2 & - \\
\hline 4. & Ilmu-Ilmu Murni & 8 & 1 \\
\hline 5. & Fiksi Indonesia & 12 & \\
\hline 6. & Manajemen Rumah Tangga dan Keluarga & - & - \\
\hline 7. & Ilmu Hayati & 3 & - \\
\hline 8. & Manajemen dan Jasa Pendukung & 2 & - \\
\hline 9. & Ilmu Pertanian dan Teknologi & 2 & - \\
\hline
\end{tabular}

122 Jurnal Perpustakaan Universitas Airlangga - Vol. 10 No. 2 Juli - Desember 2020: 116-127 


\begin{tabular}{|l|l|c|c|}
\hline 10. & Teknologi & - & - \\
\hline 11. & Teknik dan Kegiatan Berkaitan & - & - \\
\hline 12. & Kedokteran dan Kesehatan & 1 & - \\
\hline 13. & Kesenian, Hiburan dan Olahraga & 3 & - \\
\hline 14. & Perikanan & - & - \\
\hline 15. & Teknik Kimia dan Teknologi & 2 & - \\
\hline 16. & Manufaktur Produk untuk Keperluan Khusus & - & - \\
\hline 17. & Bangunan & - & - \\
\hline 18. & Geografi dan Sejarah Umum & - & - \\
\hline 19. & Perkebunan & - & - \\
\hline 20. & Ilmu Ekonomi & - & - \\
\hline 21. & Filsafat & - & - \\
\hline
\end{tabular}

(Sumber: Data olahan peneliti 2020)

Kejahatan mutilasi koleksi buku di Dinas Perustakaan dan Kearsipan Kota Lubuklinggau terbilang sangat sedikit terjadi dibandingkan dengan kejahatan vandalisme pada koleksi buku. Berdasarkan pada hasil temuan di atas buku yang paling tinggi terdampak mutilasi adalah pada rak fiksi Indonesia dengan 12 kasus buku yang sobek. Pada rak buku fiksi Indonesia terdapat berbagai jenis buku di dalamnya mulai dari majalah, novel serta buku cerita rakyat lainnya. Buku fiksi merupakan bacaan yang sangat diminati sebab isi yang terkandung didalamnya dapat menghibur pembaca, penyebab terjadinya mutilasi dapat didasari atas kesengajaan atau tanpa disengaja, faktor lainnya adalah perilaku pembaca ketika menggunakan buku yang berbeda-beda sehingga untuk tipe pembaca yang bukan merupakan teman buku akan melakukan tindakan mutilasi apabila hal demikian dibutuhkan. Sebuah hal yang menjadi perhatian adalah proses identifikasi pelaku dari mutilasi dan juga proses saat kejahatan itu berlangsung. Perpustakaan dapat menambahkan keamanan yang dapat meminimalisir hal tersebut.

\section{Peminjaman Tidak Sah (anautorized borrowing)}

Peminjaman tidak sah merupakan kegiatan peminjaman bahan pustaka tanpa melalui proses yang telah diberikan di perpustakaan. Berdasarkan temuan diatas peminjaman tidak sah yang terjadi di Dinas Perpustakaan dan Kearsipan Kota Lubuklinggau berupa tindakan meminjam buku dengan menggunakan kartu orang lain dan peminjaman tidak sah pada bagian koleksi anak SD. Berdasarkan syarat pembuatan kartu anggota yang telah dijelaskan di atas dimana calon anggota yang ingin mendaftar harus berdomisili di sekitaran Lubuklinggau yang ditunjukkan oleh kartu identitas. Hal ini yang menjadikan pengunjung yang bukan berdomisili di Lubuklinggau atau sekitarnya tidak memiliki kewenangan untuk meminjam koleksi buku di perpustakaan dan hanya saat masuk atau berkunjung dan juga membaca saja. Dengan adanya tindakan peminjaman tidak sah yang sering terjadi pada koleksi anak sekolah dasar, pihak perpustakaan selalu berupaya untuk mengurangi juga meminimalisirnya sehingga untuk sekarang ini telah tersedia kartu khusus bagi pemustaka yang masih duduk di bangku sekolah dasar. 


\section{Penanggulangan Bibliocrime di Dinas Perpustakaan dan Kearsipan Kota Lubuklinggau}

Penanggulangan bibliocrime sudah semestinya menjadi sebuah perhatian bagi para tenaga perpustakaan, sebagai salah satu cara agar tidak adanya lagi bibliocrime yang dilakukan oleh para pemustaka. Tindakan kejahatan terhadap buku dapat terjadi baik disengaja ataupun tanpa disengaja, oleh karena itu setiap perpustakaan sudah semestinya memiliki cara tersendiri untuk menanggulanginya. Berdasarkan temuan di atas bentuk penanggulangan bibliocrime di Dinas Perpustakaan dan Kerasipan Kota Lubuklinggau adalah sebagai berikut:

\section{Pencurian (Thef)}

Penanggulangan terhadap pencurian koleksi buku di Dinas Perpustkaan dan Kearsipan Kota Lubuklinggau sudah diminimalisir meskipun sejauh ini belum ada tindak pencurian koleksi buku yang terjadi. Dengan adanya penanggulangan yang dilakukan maka secara tidak langsung perpustakaan telah mempersiapkan segala kemungkinan yang nantinya akan terjadi di kemudian hari. Berikut beberapa bentuk penanggulangan yang dapat dilakukan perpustakaan selain dari apa yang telah ada seperti menambah jumlah kamera pengawas terutama pada bagian sudut-sudut ruang koleksi, melakukan pengecekan kartu anggota perpustakaan ketika hendak meminjam buku, serta pendataan identitas pelaku pencurian koleksi buku sehingga dapat memberikan sanksi dan sejenisnya kepada pelaku juga sebagai bentuk data rill.

\section{Vandalisme (Vandalism)}

Penanggulangan terhadap vandalisme di Dinas Perpustakaan dan Kearsipan Kota Lubuklinggau telah diterapkan sesuai dengan kebutuhan yang diperlukan. Tingkat vandalisme di Dinas Perpustakaan dan Kearsipan Kota Lubklinggau paling tinggi jika dibandingkan dengan bentuk kejahatan yang lainnya yaitu pencurian, peminjaman tidak sah dan mutilasi koleksi buku. Hasil temuan diatas dijelaskan bahwa tindakan vandalisme akan diketahui ketika buku telah berada di rak yang berarti pustakawan tidak mengetahui secara langsung pelaku dari vandalisme tersebut, untuk itu perlu adanya penambahan penanggulangan dari yang telah dilakukan, sehingga ketika adanya kejahatan vandalisme maka pemutaka akan mengetahuinya langsung dan dapat menjadi catatan tersendiri untuk kemudian membuat kebijakan untuk para pelaku vandalisme.

Pada dasarnya setiap perpustakaan harus melakukan pembaruan setiap waktu agar tetap dapat melindungi bahan pustaka. Penanggulangan vandalisme juga menjadi salah satu hal yang tidak boleh terlupakan, untuk terus menjaga agar koleksi tetap dalam kondisi baik tanpa adanya sesuatu hal yang dapat mengurangi kebermanfaatan buku dan tetap dapat memanjakan para pengguna perpustakaan. Penanggulangan yang dapat diberikan selain yang sudah ada adalah seperti pengecekan buku ketika proses pengembalian bahan pustaka, pemberian kamera pengawas ataupun penempatan pustakawan di dalam ruang baca untuk mengawasi jika terjadi vandalisme dan tetap ramah dengan para pengunjung perpustakaan.

\section{Mutilasi (Mutilation)}

Mutilasi koleksi buku menjadi salah satu kejahatan yang dapat membuat buku menjadi kehilangan manfaatnya bagi para pembaca, untuk itu sudah seharusnya perpustakaan membuat kebijakan untuk dapat menanggulangi kejahatan berupa mutilasi koleksi buku. Pada 124 Jurnal Perpustakaan Universitas Airlangga - Vol. 10 No. 2 Juli - Desember 2020: 116-127 
kasus ini, penanggulangan yang dilakukan oleh Dinas Perpustakaan dan Kearasipan Kota Lubuklinggau cukup dapat meminimalisir adanya tindak kejahatan mutilasi koleksi buku, berdasarkan data yang telah didapat pada temuan di atas kasus mutilasi di Dinas Perpustakaan dan Kearsipan Kota Lubuklinggau belum memiliki data pelaku kejahatan juga belum adanya data koleksi buku apa saja yang terdampak atas kejahatan ini sebab kejahatan mutilasi terhadap buku ini terdeteksi ketika pemustaka melakukan kegitan pengecekan, sehingga pustakawan perlu menambah jumlah penanggulangan dari yang telah dijelaskan di atas.

\section{Peminjaman Tidak Sah (Anautorized Borrowing)}

Penanggulangan peminjaman tidak sah telah dilakukan oleh Dinas Perustakaan dan Kerasipan Kota Lubuklinggau dengan membuat beberapa syarat ketika ingin meminjam buku untuk meminimalisir adanya peminjaman tidak sah. Berdasarkan pada temuan di atas penanggulangan peminjaman tidak sah telah dilakukan berdsarkan kebutuhan perpustakaan saat ini, namun juga perlu adanya kebjakan yang membuat kasus ini tidak terulang kembali.

\section{PENUTUP}

\section{Kesimpulan}

Berikut ini merupakan penjelasan bentuk bibliocrime yang terjadi di Dinas Perpustakaan dan Kearsipan Kota Lubuklinggau:

- Vandalisme, bentuk kejahatan terhadap buku yang penulis temui di Dinas Perpustakaan dan Kearsipan Kota Lubuklinggau yaitu dengan cara mencoret, menstabilo dan memberi tipe-x pada beberapa bagian lembaran buku juga sampul buku. Terdapat 117 buku tercoret, 3 buku distabilo dan 2 buku di tipe-X.

- Mutilasi, bentuk kejahatan terhadap buku yang terjadi di Dinas Perpustakaan dan Kerasipan Kota Lubuklinggau dengan cara merobek beberapa bagian lembaran buku juga sampul, terdapat 44 kasus koleksi buku termutilasi.

- Kasus Pencurian, terdapat kasus pencurian koleksi bahan pustaka 1 kali sebelum perpindahan gedung perpustakaan yang terakhir. terdapat bentuk lain dari pencurian bahan pustaka di Dinas Perpustakaan dan Kearsipan Kota Lubuklinggau yaitu menghilangkan buku ketika di pinjam, hal ini akan menjadi sebuah kesulitan bagi para pustakawan untuk mengidentifikasi baik pelaku juga jumlah kasus yang terjadi sehingga berakibat pada tidak adanyadta yang dapat penulis temukan.

- Peminjaman tidak sah, terdapat kasus peminjaman tidak sah di Dinas Perpustakaan dan Kerasipan Kota Lubuklinggau dengan cara meminjam kartu orang lain dan pengunaan kartu jaminan saat pemustaka tidak memiliki kartu ketika akan meminjam buku, namun pustakawan juga tidak dapat mengidentifikaasi pelaku juga jumlah dari kasus ini dikarenakan tidak adanya data tertulis.

Berdasarkan hasil di atas dapat disimpulkan bahwa bentuk bibliocrime yang terjadi di Dinas Perpustakaan dan Kearsipan Kota Lubuklinggau yaitu vandalisme, mutilasi, pencurian dan peminjaman tidak saah, namun untuk pencurian dan peminjaman tidak sah belum dapat teridentifikasi baik pelaku juga jumlah kasus yang terjadi. 
Beberapa penanggulangan yang telah dilakukan di Dinas Perpustakaan dan Kearsipan Kota Lubuklinggau adalah:

1. Pemasangan sistem kemamanan berupa kamera pengawas atau CCTV

2. Penyediaan loker untuk penitiapan tas

3. Pengawasan yang dilakukan oleh pustakwan yang menjaga ruang koleksi

4. Kartu anggota perpustakaan yang menjadi syarat untuk peminjaman

5. Penyediaan kartu khusus untuk anak-anak agar tetap bisa meminjam.

\section{Saran}

Berdasarkan hasil penelitian ini, Dinas Perpustakaan dan Kearsipan Kota Lubuklinggau pada tahun-tahun berikutnya lebih memaksimalkan tingkat pengamanan Koleksi. Memanfaatkan kecanggihan teknologi untuk memaksimalkan tingkat pengamanan koleksi. Pada penelitian selanjutnya, bisa dikaji pada tingkat pengamanan dan efektivitas tekonologi dan evaluasi tingkat pengamanan koleksi perpustakaan atau lembaga informasi yang lainnya, sehingga data dan temuan akan lebih beragam dan lebih faktual.

\section{DAFTAR PUSTAKA}

Anugrah, D., \& Ardoni. (2013). Penataan Ruangan di Perpustakaan Umum Kota Solok. Jurnal Ilmu Informasi Perpustakaan dan Kerasipan, 2.

Ardoni, D. A. (2013). Penataan Ruang di Perpustakaan Umum Kota Solok. Padang: Program Studi Ilmu Informasi Per[pustakaan dan Kerasipan FBS Universitas Negri Padang.

Barcell, F. M. (2013). Faktor0faktor penyebab terjadinya fandalisme di kantor arsip perpustakaan dan dokumentasi kota padang. Jurnal Ilmu Informasi Perpustakaan dan Kearsipan, 3.

Barcell, F., \& Marlini. (2013). Faktor- Faktor Penyebab Terjadinya Tondakan Vandalisme di Kantor Arsip Perpustakaan dan Dokumentasi Kota Padang. Jurnal Ilmu Informasi Perpustakaan dan Kearsipan Vol.2, No. 1.

Basuki, S. (1991). Pengantar Ilmu Perpustakaan. Jakarta: Gramedia Pustaka.

Daryono. (2010). Faktor-Faktor Penyebab Terjadinya Vandalisme Koleksi Perpustakaan dan Upaya Pencegahannya. Media Pustakawan vol.17 No.1, 34.

Daryono. (2010). Faktor-Faktor Penyebab Terjadinya Vandalisme Koleksi Perpustakaan dan Upaya Pencegahannya. Media Pustakawan Vol. 17 No. 1, 34.

Emzir. (2014). Metodologi Penelitian Kualitatif Analisis data. Jakarta: Rajawali Pers.

Emzir. (2014). Metodologi Penelitian Kualitatif Analisis Data. Jakarta: Rajawali Pers.

Hariri, A. (2015). Tindakan Bibliocrime di Perpustakaan Universitas Gajah Mada. Skripsi.

Hasanah, U. (2012). Bibliocrime dalam Novel The Man Who Loved Books . 3.

Hasanah, U. (2012). Bibliocrime dalam Novel The Man Who Loved Books Too Much : Kisah Nyata Tentang Seorang Pencuri, Detektif, dan Obsesi pada Kesusastraan Karya Allison Hoover Barlett. Skripsi.

Hermawan, R., \& Zen, Z. (2006). Etika Kepustakawanan: Suatu Pendekatan Terhadap Kode Etik Pustakawan Indoensia. Jakarta: Sagung Seto.

Hikmat, M. M. (2006). Metode Penelitian dalm Perspektif Ilmu Komunikasi dan Sastra. Yogyakarta: Graha Ilmu. 
Imaman, K. B. (2018). Penyalahgunaan Koleksi di Perpustakaan Nasional Republik Indonesia. Jurnal Ilmu Informasi Perpustakaan dan Kearsipan Volume 20, Nomor 2.

Lalu, M. R., Ginting, R. T., \& Suhartika, I. P. (2019). Tindakan Kebijakan Bibliocrime di UPT Perpustakaan Institut Teknologi Bandung. 2.

Maryani, L., \& Herlina. (2019). Motif Perlikau Bibliocrime di UPT Perpustakaan UIN Raden Fatah Palembang. Dalam Tamaddun: Jurnal Kebudayaan dan Sastra Islam, Vol.19 No. 1 .

Nuansa, G., \& Rohmiyanti, Y. (2017). Evaluasi Sistem Keamanan perpustakaan bagi perlindungan Koleksi di Perpustakaan Provinsi Jawa Tengah. Program Studi Ilmu Perpustakaan. Fakultas Ilmu Budaya. Semarang: Universitas Diponegoro.

Pendit, P. L. (2003). Penelitian Ilmu Perpustakaan dan Informasi : Suatu Pengantar Diskusi Epistemologi dan Metodologi. Jakarta: JIP- FSUI.

Purbaningtyas, A., \& Jumino. (2017). Penyalahgunaan Koleksi di UPT Perpustakaan Univrsitas PGRI Semarang. Skripsi.

Raharjo. (2011). Metode Pengumpulan Data Penelitian Kualitatif (Materi Kuliah Metodologi Penelitian PPS). Malang: Universitas Ilma Negeri Maliki.

Raharjo, M. (2010). Tringulasi dalam Penelitian Kualitatif. Jakarta.

Samuel, A., \& Mariana, W. (2016). Perancangan Interior Perpustakaan . Jurnal Intra, 2.

Samuel, A., \& Mariana, W. (2016). Perancangan Interior Perpustakaan Kota Surabaya Program Studi Desain Interior. Jurnal Intra Vol 4, No. 1, 2.

Saragih, Y. A. (2017). Tindakan Penyalahgunaan Koleksi : Studi Kasus di Perpustakaan Universitas Sumatera Utara.

Soendari, T. (2001). Pengujian Keabsahan Data Penelitian Data Penelitian Kualitatif Universitas Pendidikan Indonesia. Dipetik January 2, 2020, dari http://file.upi.edu/Direktori/FIP/Jur._Pend._Luar_Biasa/1956021419800

2tjutju_Soendari/Power_Point_Perkuliahan/Penelitian_PKKh/Keabsahan_data.ppt_[C ompatibility_Mode].pdf

Sugiyono. (2013). Metode Penelitian Kuantitatif, Kualitatif dan $R \& D$. Bandung: Alfabeta.

Sulistyo-Basuki. (1991). Pengantar Ilmu Perpustakaan. Jakarta: Gramedia Pustaka.

Sulistyo-Basuki. (1991). Pengantar Ilmu Perpustakaan. Jakarta: Gramedia Pustaka Utama.

Tusiver, A., \& Nelis, M. (2013). Faktor Peminjaman Tidak ah (Unauthorized Brorrowing) Bahan Pustaka oleh Pemustaka di Kantor Arsip perpustakaan dan Dokumentasi Kota Padang. Skripsi : FBS Universitas Negeri Padang. 